\title{
Revisiting the Early History of International Law
}

\author{
Daniel S. Allemann
}

\begin{abstract}
Review Article of System, Order, and International Law: The Early History of International Legal Thought from Machiavelli to Hegel, ed. by Stefan Kadelbach, Thomas Kleinlein, and David Roth-Isigkeit (Oxford: Oxford University Press, 2017).
\end{abstract}

The history of early international legal thought has become an increasingly popular and populated field in the past few decades. Intellectual historians, legal scholars, and philosophers have begun to challenge established narratives and to develop new approaches to the history of international order and the law of nations. ${ }^{1}$ The present volume takes its cue from this 'philosophical re-appreciation' of the subject and makes a significant contribution to an 'emerging discourse' (1). The sheer scope of the collection, which brings together essays by scholars from a variety of disciplinary backgrounds and academic cultures, is impressive. No less than seventeen chapters are dedicated to the examination of historical thinkers, while six further contributions probe future avenues for the study of international law's history. In contrast to the (still) received view, the story does not begin with early modern natural law theorists such as Francisco de Vitoria or Hugo Grotius, but pushes further back in time. It was Niccolò Machiavelli, as the editors insist, who first conceived of the international realm as a world of 'commonwealth[s] with interests vis-à-vis other entities of the same nature' (12). ${ }^{2}$ At the other end of the timeline, we find with G.W.F. Hegel the last great vision of international law before it became the academically institutionalized 'civilizer of nations.' ${ }^{3}$ This unusual choice of Machiavelli and Hegel as framing figures of the early history of international legal

\footnotetext{
${ }^{1}$ See e.g. Richard Tuck, The Rights of War and Peace: Political Thought and the International Order from Grotius to Kant (Oxford, UK: Oxford University Press, 1999); Antony Anghie, Imperialism, Sovereignty and the Making of International Law (Cambridge, UK: Cambridge University Press, 2004); Bardo Fassbender and Anne Peters (eds), The Oxford Handbook of the History of International Law (Oxford, UK: Oxford University Press, 2012); David Armitage, Foundations of Modern International Thought (Cambridge, UK: Cambridge University Press, 2013).

${ }^{2}$ For a recent set of contributions that trace the history of international thought to an even earlier period, see the essays in William Bain (ed.), Medieval Foundations of International Relations (Abingdon, UK: Routledge, 2017).

${ }^{3}$ The phrase is borrowed from the title of Martti Koskenniemi's The Gentle Civilizer of Nations: The Rise and Fall of International Law 1870-1960 (Cambridge, UK: Cambridge University Press, 2001).
} 
thought may come as a surprise, but it is no coincidence. Rather, it epitomizes the volume's thrust to broaden the canon and to go beyond the 'classics' of international law.

What is particularly intriguing from an intellectual history perspective is the collection's distinct take on the relationship between past thought and present concerns. As Stefan Kadelbach, Thomas Kleinlein, and David Roth-Isigkeit put it in their introduction, the overarching focus on a 'discursive sphere before the modern national state appeared' is relevant for us today insofar as 'the questions at stake' in this period are gaining renewed purchase in a time of the 'vanishing' importance of the nation-state (1-2). In placing their methodology at the intersection of contextual intellectual history and political philosophy, the editors seek to understand the primary texts in their own terms while simultaneously maintaining that there are perennial questions in international law, from Machiavelli's age to our time. What they call 'moderate anachronism' (4) is an attempt to go beyond what Ian Hunter has identified as a divide in current scholarship between progressive narratives of international law, on the one hand, and histories that conceive the law of nations merely as a tool for advancing the interests of European polities, on the other. ${ }^{4}$ The subversive and thought-provoking program of moderate anachronism, in contrast, seeks 'to combine the modesty of an observer conscious of their own bias with the imaginative force of someone who is drawing on the lessons of the past in order to put the present in perspective' (15).

In practice, this has some quite diverse manifestations. When pushed to the limits, it may become a call for moving 'beyond or behind' (76) the text itself, as Tobias Schaffner suggests in reclaiming the relevance of the Spanish scholastic theologian Francisco Suárez for international lawyers today. Conversely, co-editor Stefan Kadelbach notes in his chapter on Grotius that the approach of a moderate anachronism is not only 'methodologically contestable' but actually 'difficult to hold' (134). Thus, when asking whether 'Grotius must be left to the historians?' (157) this is not a rhetorical but quite a real question. But while a moderate anachronism may run the danger of tracing too straightforward a connection between the past and us, it can indeed open insightful new vistas. Andreas Wagner concludes his analysis of the Italian jurist Alberico Gentili by focusing on the oeuvre of scholars such as Benedict Kingsbury, who produce historical work on Gentili, and who are at the same time involved in current debates on global order. Although there is no apparent relation between the

\footnotetext{
${ }^{4}$ See Ian Hunter, 'Global justice and regional metaphysics: On the critical history of the law of nature and nations,' in Law and Politics in British Colonial Thought: Transformations of Empire, ed. by Shaunnagh Dorsett and Ian Hunter (Basingstoke, UK: Palgrave Macmillan, 2010), pp. 11-12.
} 
two fields - the historical and the contemporary - Wagner traces some conspicuous parallels between Gentili's and Kingsbury's own visions of the international and, in so doing, suggestively and subtly brings the past into a dialogue with the present.

This programmatic thrust also resonates with the volume's focus on 'system' and 'order.' In the editors' words, an integration of system and order constitutes 'a middle level between abstract and concrete' and between 'utopian and realistic aspects of international legal thought' (10). It is thus yet a further articulation of the book's endeavor to overcome the split between an understanding of international law as universal and ideal philosophy (system), and a notion of law as instrument of political power (order). Interestingly, this approach to the history of international legal thought can itself be said to be based on a particular philosophicalhistorical outlook. As Benedict Vischer notes in his contribution, it was Immanuel Kant who insisted on the 'constitutive openness' (305) of his theoretical framework, and who set out to explore 'with a pragmatic sense the real utopian perspectives harboured in law' (328). ${ }^{5}$

The volume's extensive first part is dedicated to close readings of historical theories and pays significant attention to thinkers who are not usually featured in histories of international law. This is indeed one of its most welcome and notable achievements. Merio Scattola, for instance, illuminates how Jean Bodin's theory of the international constitutes a resource for rethinking his idea of sovereignty. For Bodin, the natural law that governs the sphere beyond the république is distinct from and prior to the will of princes, but, in some ways, nevertheless extends into a given commonwealth. As Scattola maintains, turning to Bodin's international thought thus testifies to 'the fact that sovereignty cannot be so absolute' (91) after all. With the inclusion of Johannes Althusius, the volume also makes a case for the relevance of a figure who is largely absent from the history of European thought more generally speaking. According to Thomas Hueglin, the value of Althusius's theory lies in the fact that it is not grounded on the distinction between national and international law. This makes it 'of heuristic value for a post-modern system of transnational order' (115). What is more, in Christian Volk's piece we are presented with an engaging reading of the baron de Montesquieu, who crafted a complex vision of a law of nations, which at once aimed at preventing the atrocities of colonialism and slavery, and was itself implicated in the advancement of 'civilizational progress' through the 'civilized nations' (258). Equally intriguing is Bastian Ronge's analysis of Adam Smith. Although Smith had planned a work on international

\footnotetext{
${ }^{5}$ See also Ian Hunter, 'About the dialectical historiography of international law,' Global Intellectual History, 1.1 (2016), 1-32.
} 
jurisprudence, he never managed to embark on this venture. Ronge hence proposes to 'deal with a book that does not exist' (286) and concedes that 'it requires some speculative spirit to examine the possibility of international law within his framework' (283). As contentious as this approach may be from a historiographical point of view, the result is an imaginative philosophical exercise that invites us to think through the possibility of an international legal order grounded on 'a common language of emotions' (301).

A recurring theme that we encounter at several stages between the book's covers is the conception of the international realm in terms of a 'state of nature.' It was Richard Tuck who first traced the persistence of this vision in European thought, and who pointed to the 'Hobbesianism' of Jean-Jacques Rousseau and Kant's theories of world order. ${ }^{6}$ But as a number of contributors to this volume insist, they were by no means the only ones. According to David Roth-Isigkeit, we already find 'a proto-Hobbesian view of constant conflict' (31) in Machiavelli's understanding of the international. What is more, Baruch Spinoza, a further largely neglected figure in the history of international law today, equally played with the idea of a natural antagonism between states. What makes his theory particularly interesting is that in contrast to Hobbes or Rousseau, he nevertheless tried to provide a framework for the coexistence of commonwealths. In Tilmann Altwicker's words, Spinoza 'neither simply describes international relations "as they are", nor "as they should be", but rather depicts international relations "as they have the potential to be" (196). Yet another vision of global order beyond a state of nature is Christian Wolff's idealizing notion of a civitas maxima. Though not 'a homogenous world state,' it can be read as an 'an association of associations' (226) that comes about in a way reminiscent of the move from state of nature to political society. In sum, the analyses that home in on this Hobbesian lens are indicative of the volume's broader ambitions. They provide re-readings of established texts - by Thomas Hobbes himself, Samuel Pufendorf, Wolff, or Kant - as much as they introduce us to thinkers who, at least in this context, have been marginal if not passed over altogether. While each chapter is a standalone piece, taken together they bring to the fore some crucial intricacies, parallels, and dynamics of a diverse discourse on international legal thought.

The volume's second part consists of six essays that reflect on the current state and future perspectives in the history and philosophy of international law. Armin von Bogdandy and Sergio Dellavalle propose to approach the history of international law through the notions of universalism and particularism. These terms hardly appear in the legal and political language

\footnotetext{
${ }^{6}$ Tuck, The Rights of War and Peace, chs. 4 and 7.
} 
of the texts under scrutiny in this volume. But von Bogdandy and Dellavalle argue that most of the thinkers discussed can nevertheless be said to have either advocated the view that peaceful relations were only attainable among human beings within a given polity, or they subscribed to the cosmopolitan vision that "peaceful and cooperative interaction are in principle possible at a transnational and even worldwide level' (484). This lens is interesting for, in a way, it points to a history of international law beyond the volume's own chronological endpoint. Although von Bogdandy and Dellavalle defend the idea that Hegel constituted a decisive turning point, ${ }^{7}$ they suggest that the heuristic dichotomy of universalism and particularism allows for a wide-ranging approach to theories from Machiavelli to Schmitt (the 'particularists'), and from Kant to Kelsen (the 'universalists').

Quite a different idea for how the history of international law might be expanded is put forward by Martti Koskenniemi. He takes issue with the fact that, to this day, most studies in the history of international law have almost exclusively focused on notions such as 'states, sovereignty, formal diplomacy' and 'great questions of war and peace' (391). In this sense, his essay can arguably also be read as a critical take on the very volume of which it is part. For Koskenniemi, however, to fully grasp how international law was bound up with power at a given time, it is insufficient to conceive it in purely formal terms. He argues that the relevance of thinkers such as Vitoria lies not primarily in their reflections on the rights of war and conquest, but in their theorization of commercial empire through notions of private property and contract. ${ }^{8}$ Similarly, if there is a reason to include Adam Smith in the history of international law, for Koskenniemi this is not so much because he had planned to write about international jurisprudence, but because Smith extensively engaged in a transnational debate about the "jealousy of trade.' The future history of international law that Koskenniemi envisages 'could demonstrate [...] that behind every sovereign, there is some set of relations of property,' as much as it might expose that, conversely, 'every significant property relies upon state power and state institutions' (396). What Koskenniemi advocates, then, is a history of international law that revolves around the interplay of sovereignty and property, rather than solely focusing on the former. This resonates with recent trends in the history of political thought and gestures toward shared concerns in legal and contextual intellectual history. ${ }^{10}$

\footnotetext{
${ }^{7}$ On this point, see also Dellavalle's own chapter on Hegel.

${ }^{8}$ For an extended version of this argument, see Koskenniemi, 'Empire and international law: The real Spanish contribution,' University of Toronto Law Journal, 61 (2011), 1-36.

${ }^{9}$ See István Hont, Jealousy of Trade: International Competition and the Nation-State in Historical Perspective (Cambridge, MA: The Belknap Press of Harvard University Press, 2005).

${ }^{10}$ For a recent work in intellectual history, see e.g. Andrew Fitzmaurice, Sovereignty, Property and Empire, 1500-2000 (Cambridge, UK: Cambridge University Press, 2014).
} 
A further innovative approach to the history of international law that is worth briefly singling out is proposed by Thomas Duve. Focusing on the expansion of the Iberian crowns around 1500, Duve shows how the development of cosmographic knowledge gave rise to a debate in which legal claims were developed on the basis of novel understandings of space. The demarcation of the spheres of Castilian and Portuguese dominion in the Atlantic world, as established by the Treaty of Tordesillas in 1494, led to a less well-known dispute about the suzerainty over the Moluccas in the Indian Ocean. In the wake of the development of maps as globes, the line drawn in the Atlantic came to be extended to an 'antimeridian' located on the opposite side of the earth. But for decades neither the Spaniards nor the Portuguese managed to substantiate their claims, due to the 'inability of early modern cosmographers to determine the exact position of the Malacca islands' (440). Following the work of world historians such as Lauren Benton, Duve's fascinating case study underscores that the formation of early international law was intimately bound up with the making of global, geographical knowledge. ${ }^{11}$

Just like the essays on historical theories, then, the conceptual chapters present a diverse set of approaches to the history of international thought and round off an enormously comprehensive compendium that will be of interest to a wide audience. Some of the essays it assembles are more historical in scope, others take a decidedly philosophical stance, and a number of particularly outstanding chapters manage to bring together the volume's overarching aim of speaking to historians, philosophers, and those with an interest in (contemporary) international legal theory. In the face of the collection's ambition to propose a middle way between progressive and critical histories, a more comprehensive engagement with historically-minded post-colonial approaches to international law would have been desirable. ${ }^{12}$ Scholars such as Anthony Anghie have produced some of the most fruitful and influential studies in recent years, and have significantly contributed to the reevaluation of established grand narratives. ${ }^{13}$ But is the reviewer's hope to have made clear that the volume's benefits more than outweigh this minor flaw. The manifold and original ways in which it brings together historical and theoretical reflections make it a valuable and insightful resource both to those new to the field as well as to established researchers. It makes a compelling case for the turn to history in the study of international law, recovers lost ways of thinking about global order,

\footnotetext{
${ }^{11}$ See Lauren Benton, A Search for Sovereignty: Law and Geography in European Empires, 1400-1900

(Cambridge, UK: Cambridge University Press, 2009).

${ }^{12}$ Koskenniemi's essay is the notable exception.

${ }^{13}$ See above all Anghie, Imperialism, Sovereignty and the Making of International Law.
} 
and suggests how past discourses might inspire future conceptions of the international realm beyond our current worldview. 